\title{
Genetic diversity of total, active and culturable marine bacteria in coastal seawater
}

\author{
Laetitia Bernard $^{1}$, Hendrik Schäfer ${ }^{2, *}$, Fabien Joux $^{1}$, Claude Courties ${ }^{3}$, \\ Gerard Muyzer ${ }^{4}$, Philippe Lebaron ${ }^{1, * *}$ \\ ${ }^{1}$ Observatoire Océanologique, Université Pierre et Marie Curie, UMR-7621 CNRS, Institut National des Sciences \\ de l'Univers, BP 44, 66651 Banyuls-sur-Mer Cedex, France \\ ${ }^{2}$ Max-Planck-Institut für Marine Mikrobiologie, 28359 Bremen, Celsiusstr. 1, Germany \\ ${ }^{3}$ Observatoire Océanologique, Université Pierre et Marie Curie, UMR-7628 CNRS, BP 44, 66651 Banyuls-sur-Mer Cedex, \\ France \\ ${ }^{4}$ Netherlands Institute for Sea Research, 1790 AB Den Burg, Texel, The Netherlands
}

\begin{abstract}
The genetic diversity of marine bacteria from coastal Mediterranean water was analyzed using denaturing gradient gel electrophoresis (DGGE) and comparative sequence analysis of PCR-amplified 16S rRNA genes. The diversity of the whole bacterial assemblage was compared to the diversity of the fraction of actively respiring bacterial cells and of culturable bacteria. Culturable bacteria were isolated on agar plates using 4 different culture media, as well as in filtered autoclaved seawater following dilution to extinction. The cell fractions exhibited varied genetic diversity. High similarity between DGGE patterns obtained from the whole bacterial assemblage and those obtained from the active cell fraction (representing only $3 \%$ of total cells) indicated the simultaneous presence of both active and inactive cells within populations corresponding to numerous bacterial phylotypes defined as DGGE bands. Furthermore, an important source of genetic diversity corresponding to viable organisms, detected by culturability on agar media and in dilution culture with unamended seawater, was not detectable by DGGE patterns obtained from total cells. Most of the strains isolated by dilution cultures were different from those isolated on solid agar media. These results suggest that studies on the structure of complex marine bacterial communities do not necessarily reflect the physiological heterogeneity of ecologically important populations and may ignore populations present at low relative abundance that can play a key ecological role.
\end{abstract}

KEY WORDS: Activity $\cdot$ Cell sorting $\cdot$ Culturability $\cdot$ Genetic diversity $\cdot$ Marine bacteria $\cdot$ Oligotrophy

Resale or republication not permitted without written consent of the publisher

\section{INTRODUCTION}

A major question in microbial ecology is which members of bacterial communities are responsible for the overall activity and/or productivity, and what factors control the activity or inactivity, of in situ populations. New methodological approaches were recently proposed to relate community structure to community activity (Lee et al. 1999, Urbach et al. 1999). However,

* Present address: Netherlands Institute for Sea Research, 1790 AB Den Burg, Texel, The Netherlands

${ }^{* *}$ Corresponding author. E-mail: lebaron@obs-banyuls.fr. the relationships between the diversity of species identified at the community level, within the pool of active cells and from isolates, remain poorly understood.

To better understand the physiology and ecology of bacterial species, their isolation in pure culture remains an essential step in microbial ecology. For the marine environment, colony forming units (CFU) provide an inadequate description of the relative abundance of bacteria, because traditional cultivation methods do not mimic the real environmental conditions under which natural populations flourish (Ward et al. 1990). The culturability of a bacterial cell is a species-dependent characteristic. Many marine bacterial species have unknown growth requirements and have 
not yet been cultured. Several media with different compositions have been proposed for isolating new species (Martin \& MacLeod 1984, Gonzalez \& Moran 1997) and a dilution culture technique has been developed to isolate oligotrophic species, which do not grow on nutrient-rich medium (Button et al. 1993). However, culturability is also a function of the physiological state of a cell, and cells of cultured species may become unculturable under adverse environmental conditions (Schut et al. 1997). Recent studies have demonstrated that, even if the CFU proportion remains very low, cultured species sometimes represent a significant part of the community DNA (Pinhassi et al. 1997). This suggests that non-culturable cells of cultured species may represent a numerically important fraction of natural communities.

Different culture-independent methods have been developed to quantify metabolically active bacteria in natural communities (Joux \& Lebaron 2000). Among these, the detection of actively respiring cells via cellspecific reduction of the fluorogenic dye 5-cyano-2,3ditolyl tetrazolium chloride (CTC; Polyscience Europe) is often considered as one of the most universal methods applicable for complex natural communities. Although this method remains controversial (Thom et al. 1993, Lovejoy et al. 1996, Ullrich et al. 1996, Sieracki et al. 1999), it has been shown that active cell counts vary in an ecologically interpretable manner (del Giorgio \& Scarborough 1995, Smith 1998, Sherr et al. 1999). The proportion of actively respiring cells is generally below $10 \%$ in aquatic ecosystems (Lovejoy et al. 1996, Karner \& Fuhrman 1997). However, the general acceptance of this method by microbial ecologists requires more investigation.

Molecular methods, particularly those using the $16 \mathrm{~S}$ rRNA gene as a molecular marker, are commonly used in microbial ecology studies as cultivation-independent tools to analyze the structure of microbial communities and to identify uncultured species. These methods have proven useful to provide a more accurate description of the diversity, structure, and dynamics of complex microbial communities (Muyzer 1998). However, these methods are also subject to several limitations (Amann et al. 1995, Wintzingerode et al. 1997, Head et al. 1998). For example, rRNA gene fragments of less-abundant microorganisms tend to be underrepresented in polymerase chain reaction (PCR) amplification. It could be argued that these underrepresented populations are likely to be of minor ecological importance in a given ecosystem, but one should realize that in most aquatic ecosystems, only a small fraction of the community is active at any given time (Lovejoy et al. 1996, Karner \& Fuhrman 1997, Choi et al. 1999). Therefore, the community structure derived from the analysis of the whole DNA includes active, inactive and dead cells. Methods which provide information on the structure of viable and active cells should be very useful for investigating the relationships between diversity and activity.

The aim of this study was to compare the genetic diversity of cells isolated by different culture techniques and that of active cells detected by the CTC method with the genetic diversity commonly determined at the community level. Isolates were recovered by using 4 different culture media and the dilution culture technique whereas active cells were detected by CTC staining and then sorted by FCM. The genetic diversity within each cellular fraction as well as that of the whole community was investigated by the denaturing gradient gel electrophoresis (DGGE) method and profiles were compared. Some isolates and some bands from the DGGE gels were sequenced for identification.

\section{MATERIALS AND METHODS}

Sampling. Mediterranean seawater was collected at $2 \mathrm{~m}$ depth in the Bay of Banyuls-sur-Mer $\left(42^{\circ} 31^{\prime} \mathrm{N}, 03^{\circ}\right.$ $11^{\prime}$ E) on November 2, 1998. Sampling was performed using a Niskin bottle and the seawater was processed in the laboratory within $1 \mathrm{~h}$ of sampling. All analyses were performed on natural seawater without any prefiltration step to avoid the potential effect of filtration on community structure. A flow chart of the experimental design is presented in Fig. 1.

Flow cytometric analysis of the natural bacterial assemblage. The total number of bacterial cells was determined using the nucleic acid stain SYBR Green II (Molecular Probes Inc., Eugene, OR, USA) and flow cytometry (FCM) as described by Lebaron et al. (1998b). Briefly, a volume of natural seawater was fixed with $2 \%$ (w/v, final concentration) formaldehyde, and stored in liquid nitrogen before analysis. The sample was thawed and a $1 \mathrm{ml}$ subsample was incubated with SYBR Green II (final concentration $0.05 \%$ [v/v] of the commercial solution) for at least $15 \mathrm{~min}$ at $20^{\circ} \mathrm{C}$ in the dark prior to analysis using a FACSCalibur flow cytometer (Becton Dickinson, San Jose, CA, USA). The FACSCalibur is equipped with an air-cooled argon laser (488 nm, $15 \mathrm{~mW})$. Stained cells were enumerated according to their side angle scattered light (SSC) and green cell fluorescence (FL1) collected through a $530 \pm$ $30 \mathrm{~nm}$ band pass filter. Yellow-green fluorescent beads (1 um diameter, Polysciences Inc., Warrington, PA, USA) were systematically added to each analyzed sample to normalize SSC and FL1 emission. Data acquisition and analysis were done with Cell-Quest software (Becton Dickinson). Acquisition was triggered by FL1. The precise volume analyzed and subsequent estimation of cell concentrations were calculated by measur- 


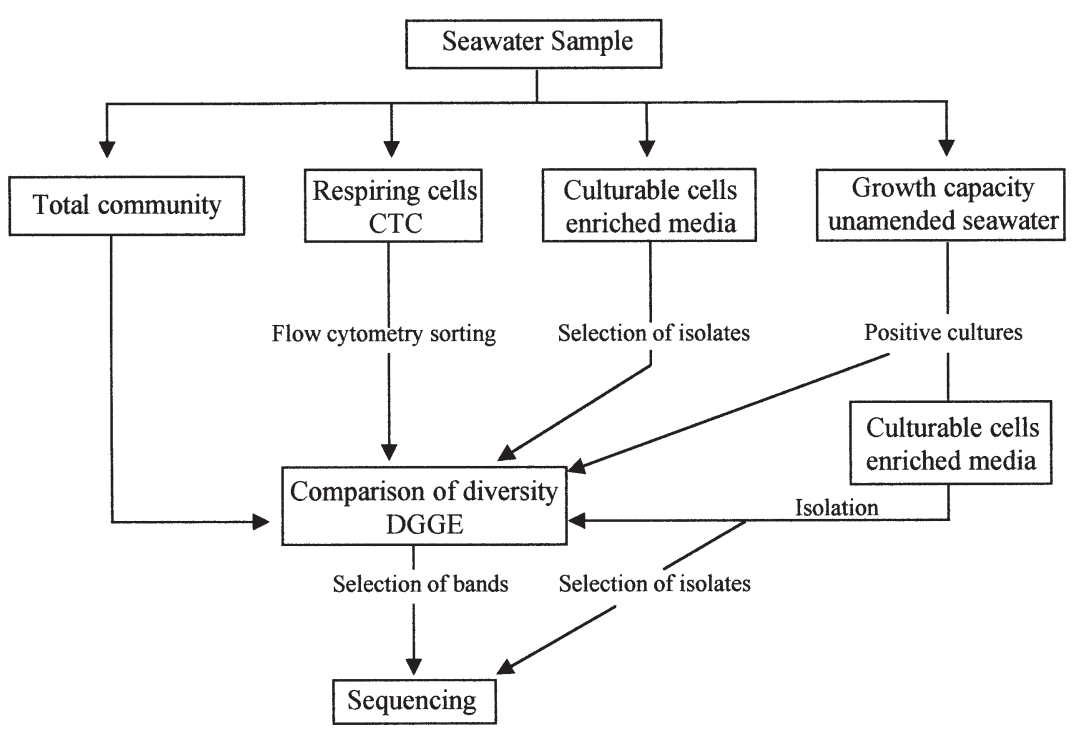

Fig. 1. Flow chart of the strategy for comparing the genetic diversity from microbial communities, respiring cells, culturable cells, and strains obtained from the dilution cultures

ing the remaining volume and subtracting it from the

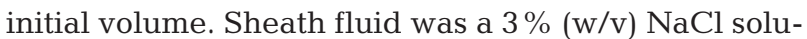
tion filtered through a $0.45 \mu \mathrm{m}$ pore size membrane.

Microscopic counts and flow cytometric cell sorting of respiring cells. Respiring cells were determined as those capable of reducing the non-fluorescent tetrazolium salt CTC to its fluorescent counterpart (Rodriguez et al. 1992). CTC was added at a final concentration of $2.5 \mathrm{mM}$ to $2 \mathrm{ml}$ aliquots dispensed into plastic tubes. The samples were incubated for $8 \mathrm{~h}$ in the dark at ambient temperature. After incubation, samples were fixed with formaldehyde $(2 \%$ [w/v], final concentration) and stored at $4{ }^{\circ} \mathrm{C}$, until they were analyzed by epifluorescence microscopy and FCM. Simultaneous counts of the total and respiring cells were performed by epifluorescence microscopy. These counts could not be obtained by FCM due to an overlap of fluorescence between SYBR Green II and CTC dyes and because the UV laser applicable to DAPI (4', 6-diamidino-2-phenylindole) was not operational on the flow cytometer. For microscopic analysis, cells were counterstained with DAPI at a final concentration of $2.5 \mu \mathrm{g} \mathrm{ml}^{-1}$ followed by filtration onto $0.2 \mu \mathrm{m}$ pore size black polycarbonate filters. The fraction of respiring cells was determined as the ratio of CTC-positive (CTC+) cells to total DAPIstained cells for each microscopic field, as previously described (Joux \& Lebaron, 1997). Proportions of actively respiring cells were also determined for samples incubated with yeast extract ( $50 \mathrm{mg} \mathrm{l}^{-1}$, final concentration) and CTC (2.5 mM, final concentration) for $4 \mathrm{~h}$. The respiring cell fractions (with and without additional substrate) were calculated as the mean of 3 replicates.
After staining and fixation, respiring cells obtained with addition of substrate were sorted using a FACSVantage flow cytometer (Becton Dickinson). The $488 \mathrm{~nm}$ emission line of a $100 \mathrm{~mW}$ water-cooled laser was used for measuring orange-red fluorescence emitted by respiring cells. Sort criteria were defined by drawing polygonal gates in bivariate histograms of orange fluorescence (FL2) (565 to $605 \mathrm{~nm}$ band pass) plotted against red fluorescence (FL3) (650 nm and above) fluorescence values. The FL3 versus FL2 cytogram obtained from the analysis of CTC+ cells, indicating the sorting gate, is presented in Fig. 2. Cells were sorted at a speed ranging from 200 to 300 cells s ${ }^{-1}$ and collected in sterile plastic tubes. A sterile and nucleic acid-free solution of phosphate-buffered-saline (PBS) $\mathrm{Ca}^{2+}$ and $\mathrm{Mg}^{2+}$ free (Dulbecco, Eurobio, France) was used as sheath fluid to minimize salt interference with the PCR. Due to the high number of cells required for genetic analysis, CTC staining with addition of substrate was performed on $20 \mathrm{ml}$ samples.

Enumeration and isolation of culturable cells. CFU counts were performed using 4 different agar media: (1) Marine agar (MA; Difco, Detroit, MI, USA); (2) R2A (Difco) prepared with $75 \%$ (v/v) filtered $(0.45 \mu \mathrm{m}$ pore size) aged seawater (R2Am); (3) a 9 salts solution with $1 \mathrm{~g} \mathrm{l}^{-1}$ peptone, $0.5 \mathrm{~g} \mathrm{l}^{-1}$ yeast extract and $0.5 \mathrm{~g} \mathrm{l}^{-1}$ glucose (VNSS; Eguchi et al. 1996); and (4) a 7 salts solution with $0.25 \mathrm{~g} \mathrm{l}^{-1}$ bactopeptone (PPES-II; Martin

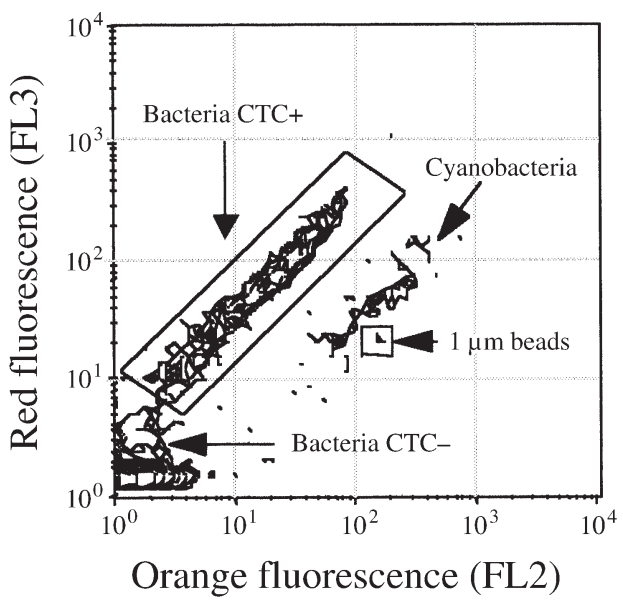

Fig. 2. Flow cytometric analysis (orange fluorescence [FL2] vs red fluorescence [FL3]) of the parent seawater stained with CTC dye. CTC+ cells are circumscribed in the gate used for cell sorting 
\& MacLeod 1984). Samples were serially diluted in autoclaved seawater, and $100 \mu \mathrm{l}$ of each dilution was plated on each medium with 5 replicates. Counts were made after 7 and $15 \mathrm{~d}$ of incubation at room temperature. The percentage of CFU was determined as the ratio of CFU to total cell counts.

Analysis of the genetic diversity of culturable cells involved mixing all different colony morphotypes, from 3 plates of each medium, in $1 \mathrm{ml}$ of pure water (Sigma). We assume that on a given medium, different morphotypes correspond to different species whereas different species may have the same morphotype (Lebaron et al. 1998a). For each morphotype, 3 or 4 colonies were randomly selected and picked out. This procedure was used to group together the largest number of different genotypes found on a given medium and to analyze their diversity on a single DGGE profile. This approach was more convenient for comparing the genetic diversity of cells growing on different media. In order to avoid some bias due to a significant variability in the number of cells picked out within each colony, pieces of the collected colonies had approximately similar sizes. Similarly, small colonies were collected and processed separately. Cell suspensions were stored at $-20^{\circ} \mathrm{C}$ before analysis.

Dilution cultures. Dilution cultures were performed as described by Button et al. (1993). The growth medium was prepared previously by collecting seawater from the same site, filtering it through $0.2 \mu \mathrm{m}$ pore-sized polycarbonate filters (GTTP, Millipore), autoclaving at $121^{\circ} \mathrm{C}$ for $15 \mathrm{~min}$, and filtering again to eliminate the precipitated salt. Flasks $(100 \mathrm{ml})$ were filled with $80 \mathrm{ml}$ of the growth medium and autoclaved. A natural seawater subsample was diluted with the unamended growth medium and dispensed into flasks using the appropriate volume in order to obtain a total of 100,50,10, 5 and 1 cells per flask, respectively. Each dilution for the flasks containing 100, 50 and 10 cells was processed in 10 replicates; 20 replicates were made for the flasks containing 5 cells, and 30 replicates for the flasks containing 1 cell. After inoculation, the 80 flasks were incubated in the dark at $15^{\circ} \mathrm{C}$ for 3 mo. Growth was examined at the end of the incubation period by enumerating the total number of cells using FCM as described previously for natural seawater. The proportion of viable bacteria was calculated using the relationship described by Button et al. (1993). Flasks in which growth was observed were assayed for culturability by plating subsamples onto R2Am agar plates. Highest colony counts were found on this medium during preliminary experiments performed on seawater collected at the same site. Additionally, for each dilution, water from 1 flask in which growth was observed was plated onto agar plates of the 4 different media. For each flask, all morphotypes were enumerated and 3 to 4 colonies of each were isolated.
Cell lysis and PCR amplification of 16S rRNA genes. Total bacterial cells from seawater samples $(20 \mathrm{ml}$ subsample), respiring cells sorted by FCM (a minimum of $10^{6}$ cells), and dilution cultures (50 ml subsamples) were collected by filtration onto $0.2 \mu \mathrm{m}$ pore size polycarbonate filters (GTTP, Millipore, France). Filters were stored at $-20^{\circ} \mathrm{C}$ before further analysis. To extract DNA, cell fractions were subjected to a lysis protocol. Briefly, each filter was cut into small pieces using a sterile scalpel, collected in a sterile $1.5 \mathrm{ml}$ Eppendorf tube, and resuspended in $200 \mu \mathrm{l}$ of lysis solution as described by Garcia-Pichel et al. (1996). For culturable cells, DNA extraction was performed on the mix of colonies collected from 1 of the 4 media for DGGE analyses or directly on isolates for sequencing analyses. When applied to the mix of colonies, $3 \mu$ l of the mix were added to $50 \mu \mathrm{l}$ of lysis solution. When applied to an isolate, $50 \mu \mathrm{l}$ of the cell suspension were added to the lysis solution. Cell lysis was performed as described by GarciaPichel et al. (1996) using 3 freeze-thaw cycles and a Proteinase $\mathrm{K}$ digestion step for $1 \mathrm{~h}$ at $55^{\circ} \mathrm{C}$.

A 550 bp $16 \mathrm{~S}$ rDNA fragment, including the variable V3 region, was amplified (Muyzer et al. 1995) using a HYBAID Touchdown thermocycler (HYBAID Ltd, Teddington, UK). Primers 341f and 907R* (Primer 907R with a cytosine at position 916) were used for the reaction. An additional 40 nucleotide GC-rich sequence (GC-clamp) was added to the $5^{\prime}$ end of primer $341 \mathrm{f}$. Twenty $\mu$ l of lysates from cells collected on filters, and $3 \mu \mathrm{l}$ of lysates from culturable cells were used as a template in $100 \mu \mathrm{l}$ of PCR reaction mix $(1 \times$ PCR buffer, $50 \mathrm{nM}$ primers, $0.25 \mathrm{nM}$ of each dNTP, $1.5 \mathrm{mg} \mathrm{ml}^{-1}$ bovine serum albumine). One unit of Super-Taq Polymerase (HT Biotechnology Ltd, Cambridge, UK) was added after $5 \mathrm{~min}$ of a $94^{\circ} \mathrm{C}$ 'hot start'. The program used for amplification also included a 20 cycle 'touchdown step', whereby the annealing temperature decreased from 65 to $55^{\circ} \mathrm{C}$, followed by 15 cycles with a constant annealing temperature of $55^{\circ} \mathrm{C}$. PCR amplifications were checked on $1 \%(\mathrm{w} / \mathrm{v})$ agarose gel before DGGE analysis.

DGGE analysis of 16S rRNA gene fragments. DGGE was performed with a D-Code system (Bio-Rad, Hercules, CA, USA) following the protocol described by Muyzer et al. (1998). DGGE was maintained at a constant temperature of $60^{\circ} \mathrm{C}$ in $1 \times$ TAE-buffer $(20 \mathrm{mM}$ Tris $10 \mathrm{mM}$ acetate, $0.5 \mathrm{mM}$ EDTA, pH 8.3). Denaturing gradients were formed of 20 and $60 \%$ urea-formamide. Gels were run at $200 \mathrm{~V}$ for $4 \mathrm{~h}$. Thereafter, the gels were stained in an ethidium bromide solution $(0.5 \mu \mathrm{g}$ $\mathrm{ml}^{-1}$ ), destained in water, and photographed under ultraviolet illumination. The photographs were scanned and treated using PhotoDeluxe software (Adobe, Inc., Mountain View, CA, USA). Images were reversed, and the luminosity and contrast of some individual lanes were balanced in respect of other lanes on the same gel. 
Sequencing and comparative sequence analysis. Bands of interest were cut from the gel using a sterile scalpel and stored in $0.5 \mathrm{ml}$ reaction tubes at $-20^{\circ} \mathrm{C}_{\text {; }}$ afterward they were washed with $200 \mu \mathrm{l}$ of sterile water for $1 \mathrm{~h}$ at room temperature. After decantation, $30 \mu \mathrm{l}$ of fresh sterile water were added and the bands were incubated at $4^{\circ} \mathrm{C}$ overnight. DNA from the excised bands, as well as DNA from isolates, were reamplified by PCR, and PCR products were checked for the presence of a single band with DGGE. PCR products were sequenced using the BigDye terminator ready reaction cycle sequencing kit (Perkin Elmer, Foster City, CA, USA) using primers 341f (without GCclamp) and $907 \mathrm{R}^{*}$. Due to the restricted amount of PCR product, DGGE bands could only be sequenced using primer 341f. Sequencing reactions were analyzed on an ABI-310 Genetic Analyzer.

Partial sequences were analyzed using the BLAST (Altschul et al. 1990) program at the NCBI database and added together with the highest scoring BLASThits to an alignment of about 5300 homologous bacterial 16S rRNA primary structures (Maidak et al. 1997) by using the aligning tool of the ARB software package (Strunk \& Ludwig 1998). Neighbor-joining analysis was carried out with the correction method of Felsenstein, as implemented in ARB of the fragment between Escherichia coli positions 375 and 875 taking only nucleotide positions conserved to at least $50 \%$ in Bacteria into account. The resulting tree was obtained by inserting new sequences into a tree derived from almost complete sequences by using the ARB parsimony tool that enables a reliable positioning of new sequences without allowing changes of the overall tree topology (Ludwig et al. 1998).

Nucleotide accession numbers. The nucleotide sequence data reported here have been deposited in the European Bioinformatics Institute nucleotide sequence databases under the accession numbers AJ250894 to AJ250899.

\section{RESULTS}

\section{Cell counts}

Cell counts determined by the different methods are reported in Table 1. Total cell counts in natural seawater were determined by FCM (Fig. 3a). While the concentration of bacteria was $6.8 \times 10^{5}$ cells ml$^{-1}, 2$ populations of cells were clearly separated, corresponding to cells with a similar mean SSC value, but differing by their nucleic acid content (GI and GII groups). These 2 groups represented $54.8 \%$ (GI) and $45.2 \%$ (GII) of total bacterial abundances, respectively. The proportion of actively respiring cells as determined by the CTC
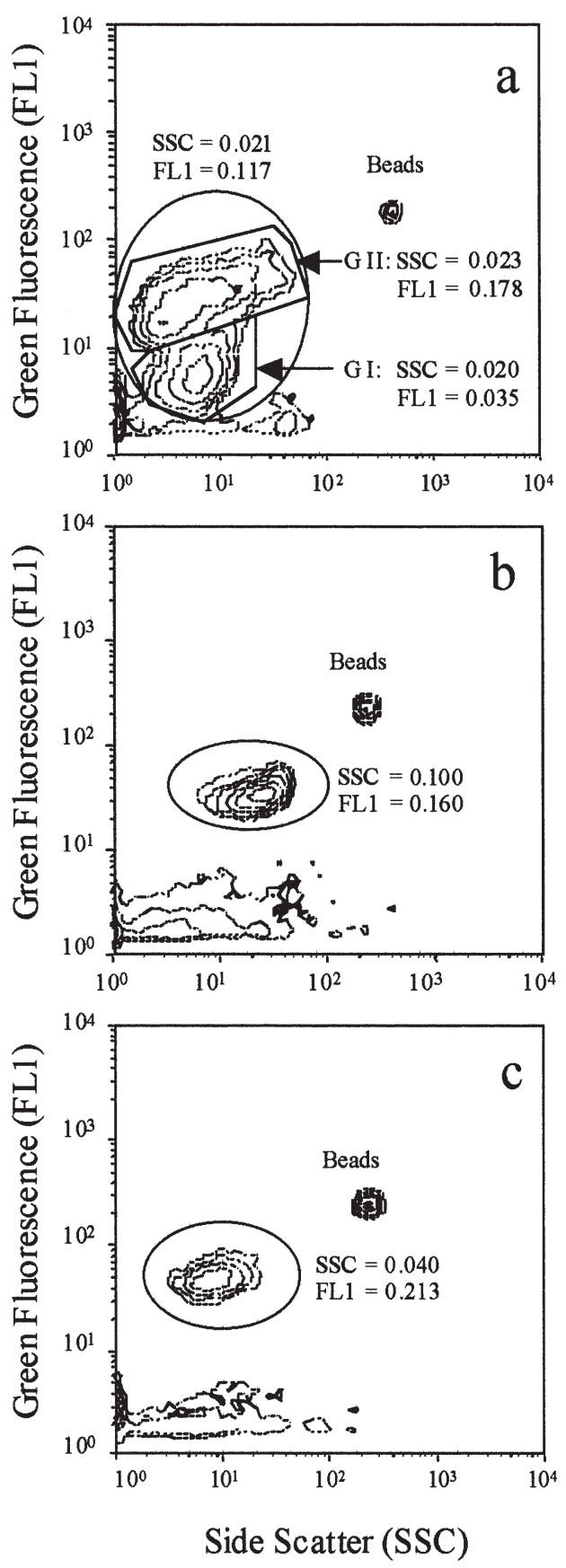

Fig. 3. Flow cytometric analysis (side scatter [SSC] vs green nucleic acid fluorescence [FL1]) of (a) the initial seawater and strains, (b) DILs-1 and (c) DILs-2, obtained after growth in dilution cultures inoculated with 50 and 100 cells respectively. Mean ratio of populations SSC and FL1 values versus the bead values are indicated

method (Table 1) was not significantly different ( $t$-test, $p<0.05)$ for CTC+ cells incubated with yeast extract. However, the mean fluorescence intensity of respiring cells was increased in the presence of nutrients and the fluorescence signal was clearly distinct from the fluo- 
Table 1. Concentrations of total, actively respiring and culturable bacterial cells in natural seawater. Total counts were determined by FCM after staining the cells with SYBR Green II. Actively respiring cells were enumerated by microscopic examination using the CTC method with or without addition of yeast extract (YE). Culturable cell counts were determined by using 4 different culture media (R2Am, MA, VNSS and PPES-II), and by the dilution culture technique. Results are also given as percentages of total cell counts determined by FCM

\begin{tabular}{|lcc|}
\hline Parameter & Cell ml & Percentage of total count \\
\hline Total count & $6.80 \times 10^{5}$ & 100 \\
Actively respiring cells & & \\
CTC & $1.37 \times 10^{4} \pm 0.12$ & $2.01 \pm 0.18$ \\
CTC + YE & $2.08 \times 10^{4} \pm 0.78$ & $3.06 \pm 1.15$ \\
Culturable cells & & \\
R2Am & $1.73 \times 10^{4} \pm 0.06$ & $2.54 \pm 0.09$ \\
MA & $1.31 \times 10^{4} \pm 0.09$ & $1.93 \pm 0.13$ \\
VNSS & $0.99 \times 10^{4} \pm 0.15$ & $1.46 \pm 0.22$ \\
PPES-II & $0.80 \times 10^{4} \pm 0.15$ & $1.18 \pm 0.22$ \\
Dilution cultures & $1.09 \times 10^{4} \pm 0.43$ & $1.61 \pm 0.63$ \\
\hline
\end{tabular}

rescence background (Fig. 2). This condition was therefore selected for sorting active cells by FCM and for subsequent molecular analysis.

The proportion of culturable bacteria varied depending on the media used for their detection. Statistical analysis ( $t$-test, $\mathrm{p}<0.05$ ) revealed that the R2Am medium had a significantly higher percentage of CFU than either MA, VNSS, and PPES-II media. Similarly, the number of culturable cells on MA medium was significantly higher $(t$-test, $\mathrm{p}<0.05)$ than that on VNSS and PPES-II media.

\section{Growth of cells in dilution cultures}

Bacterial cells were diluted to extinction with sterilized unamended seawater from the same source, and growth was evaluated by FCM after 3 mo of incubation. Populations consistently developed in 17 of the 80 flasks and growth was never detected in flasks inoculated with a single cell. The concentration of cells in growth-positive flasks ranged from $1.93 \times 10^{4}$ to $8.22 \times 10^{5}$ cells $\mathrm{ml}^{-1}$. The proportion of viable cells, as $(1.61 \%)$ determined by the number of positive cultures (Button et al. 1993), was not significantly different from those of $\mathrm{CTC}+$ and culturable cells on MA medium ( $t$-test, $\mathrm{p}<0.05$ ) (Table 1). The populations developed in dilution cultures were analyzed by FCM and cytograms of 2 populations found in many flasks are given in Fig. 3b,c. The comparison of these characteristics between all dilution cultures and the initial natural sample (Fig. 3a) showed that cells grown in flasks have similar size and nucleic acid contents to those belonging to the GII group of the natural community. Furthermore, in a recent study, bacteria with apparent high DNA content and corresponding to our GII group have been shown to represent the actively growing part of the community (Gasol et al. 1999).

The proportion of growth-positive flasks determined at different dilutions (numbers of inoculated cells per flask) are reported in Table 2. For each positive flask, all colonies had a uniform morphology upon isolation, suggesting the growth of a single species. All colony morphotypes isolated from growth-positive flasks were compared by DGGE analysis in order to eliminate redundant strains (same morphotype and phylotype). A total of 7 different strains was found and referenced DILs-1 to DILs-7 (Table 2). Some of the strains were not culturable onto R2Am in primary culture but all were able to grow on this medium in secondary culture (Table 2).

Despite the heterogeneity of $16 \mathrm{~S}$ rDNA reported previously for other marine isolates (Dahllof et al. 2000), all the DILs strains gave a single band on DGGE gel (Fig. 4). Alternatively, the composition within each growth-positive flask was also analyzed directly by DGGE. As the DGGE profile obtained from each flask showed no bands different from those obtained from the whole isolates, all genotypes detected in the flasks were cultured strains. However, for some flasks where a single colony morphotype was detected, 2 bands were observed on DGGE gels. This second band may be related to a strain composed by dead or noncultur-

Table 2. List of strains recovered from the dilution cultures. ${ }^{*}$ Not recovered on R2Am upon the first isolation from the culture flasks

\begin{tabular}{|c|c|c|}
\hline $\begin{array}{l}\text { No. of cells inocu- } \\
\text { oculated per flask }\end{array}$ & $\begin{array}{c}\text { Proportion of } \\
\text { growth-positive flasks }\end{array}$ & Strains found in the different flasks ${ }^{a}$ \\
\hline 100 & $8 / 10$ & $\begin{array}{l}\left(\text { DILs-1, DILs-2* }{ }^{*}\right) ;(\text { DILs-1, DILs-2*); } \\
\left(\text { DILs-1, DILs-2 }{ }^{*}\right) ;\left(\text { DILs-2* }{ }^{*}, \text { DILs-4 }{ }^{*}\right) ; \\
(\text { DILs-1); (DILs-2); (DILs-2); (DILs-2) }\end{array}$ \\
\hline 50 & $6 / 10$ & $\begin{array}{l}\text { (DILs-1* }{ }^{*}, \text { DILs-6); }\left(\text { DILs-6* }{ }^{*} \text { DILs-7); }\right. \\
\text { (DILs-1); (DILs-1); (DILs-5); (DILs-7) }\end{array}$ \\
\hline 10 & $2 / 10$ & (DILs-1); (DILs-2) \\
\hline 5 & $1 / 20$ & (DILs-1* ${ }^{*}$ DILs-7) \\
\hline 1 & $0 / 30$ & No strains \\
\hline
\end{tabular}


a

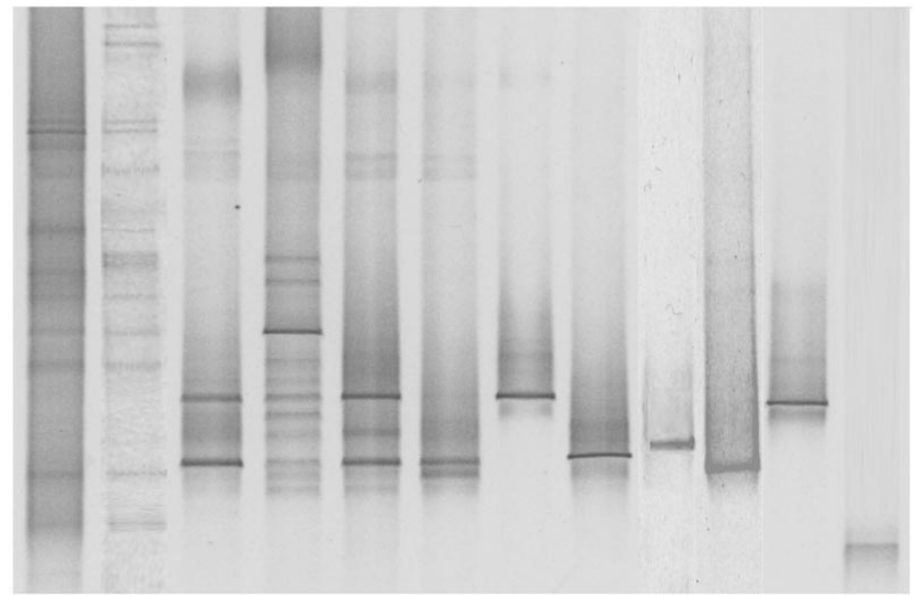

b

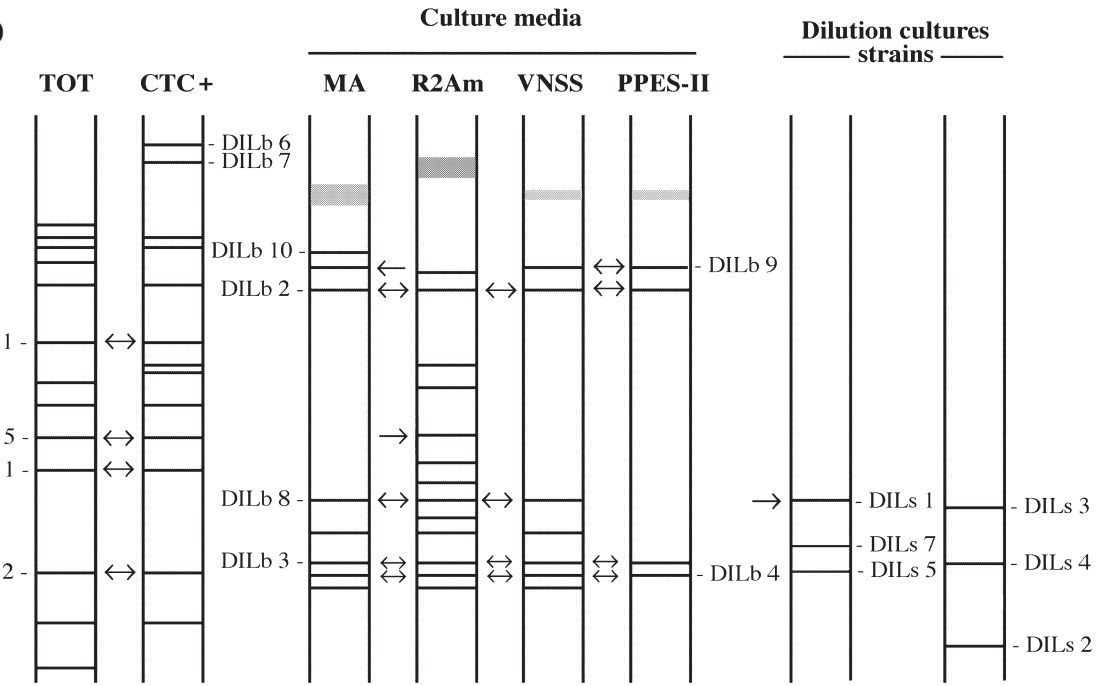

Fig. 4. DGGE pattern from total community (TOT), actively respiring cells $(\mathrm{CTC}+)$, cells grown on different agar media (MA, R2Am, VNSS, PPES-II) and strains grown in dilution cultures. (a) Banding pattern of the original gel stained with ethidium bromide. (b) Schematic drawing of the banding pattern

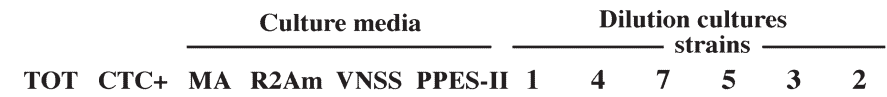

bands were found in TOT and CTC+ profiles and 9 of these bands were common to both profiles.

The DGGE profiles of culturable cells isolated from the natural community exhibited great variations in the number of bands depending on the culture medium (14 bands for R2Am, 9 for MA, 8 for VNSS, 5 for PPES-II). These differences may be related to those found between $\mathrm{CFU}$ counts due to the variable selectivity of these media. Only 3 bands (DILb-2, -3 and -4$)$ were common to DGGE profiles corresponding to the 4 culture media. The bands found in the PPESII profile were present in the profile of other media, which suggests that PPES-II medium is highly selective and does not allow the detection of strains different than those found in other media. Among the different bands found in culture media profiles, DILb-3 and -8 had similar migration distances to those obtained for isolates DILs-4 and DILs-1 from the dilution cultures, respectively. Difficulties in DNA amplification prevented the inclusion of DILs-6 in this comparison.

Most of the bands found in DGGE profiles from culture media were not found in the community DNA profile (TOT). Only 1 band (DILb-5) was common to the TOT, R2Am and CTC+ profiles. Similarly, only 1 DIL strain band (DILs-5) was found in the TOT and CTC+ profiles (corresponding to DILb-12). However, the similar migration distances of these bands should be considered cautiously.

\section{Identification of strains}

able cells (due to the presence of a second species), or cells present at a much lower concentration in the flasks (their colonies were not detected on plates).

\section{Comparison of DGGE profiles}

The DGGE profile obtained from community DNA (TOT), actively respiring cells (CTC+), culturable cells isolated on different agar media (R2Am, MA, VNSS and PPES-II) and cells grown in the dilution culture are reported in Fig. 4a. The schematic position of each band is shown in Fig. 4b. Bands which are discussed in the text are referenced DILb-1 to DILb-12. A total of 13
Four of the 7 strains isolated from dilution culture were identified by sequencing. Two strains (DILs-1 and -2) were selected, because they were present in most growth-positive flasks, whereas 2 other strains (DILs-3 and -4) were only found in a few flasks. The phylogenetic position of these strains, deduced by partial sequence analyses of approximately $500 \mathrm{bp}$, is shown in Fig. 5. Strain DILs-1 was affiliated with the $\alpha$ subclass of Proteobacteria and closely related to Erythromicrobium sp. strain RE35F/1 (99.6\% sequence similarity). Strains DILs-2 and DILs-3 belong to the 


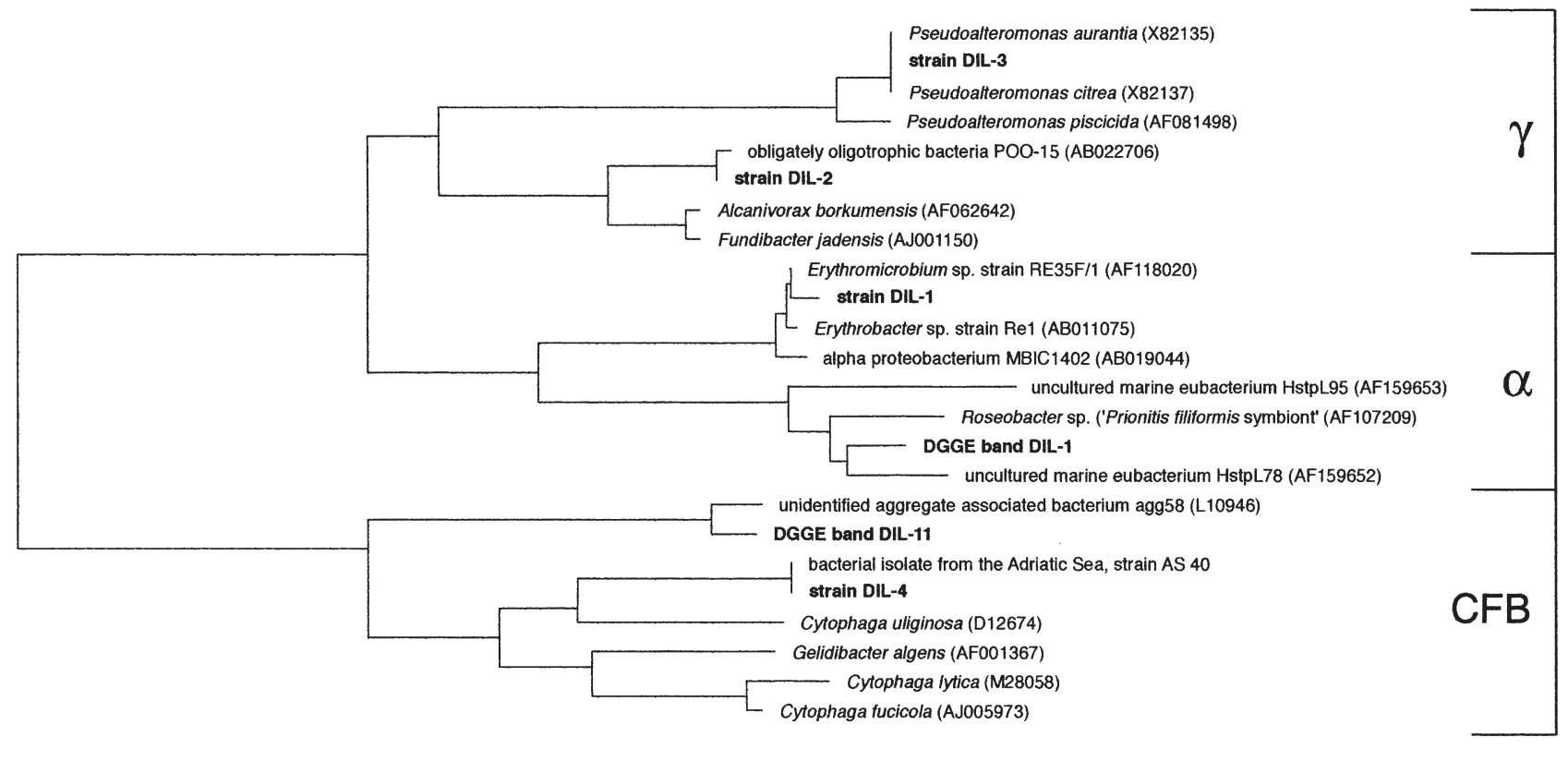

Fig. 5. Neighbor-joining tree showing the relationships of strains isolated in this study and of bands excised from DGGE gels to various reference taxa from the $\alpha$ and $\gamma$ gamma subdivisions of the Proteobacteria and the Cytophaga-Flavobacterium-Bacteroides (CFB) phylum. Sequences determined in this study are shown in bold. The accession numbers of the reference sequences used in the calculation are reported in parentheses. The scale bar represents $10 \%$ estimated sequence divergence. Details on how the tree calculation was done are described in 'Materials and methods'. The sequence of the bacterial strain AS40 isolated from the Adriatic Sea was kindly provided by Céline Fajon

$\gamma$-subclass of Proteobacteria. Strain DILs-2 was closely related to a marine obligate oligotroph POO13 $(99.8 \%$ similarity) and more distantly to Fundibacter jadensis (94.6\% similarity), whereas strain DILs-3 was closely related to Pseudoalteromonas citrea (99.6\% similarity). Strain DILs-4 was $99.2 \%$ similar to a strain isolated from the Adriatic Sea (strain AS-40; Fajon pers. comm.), these strains were distantly related to Flavobacterium uliginosum (90\% similarity).

Two of the numerous bands present in both TOT and CTC+ DGGE profiles (DGGE bands DILb-1 and -11) were also partially sequenced. DILb-1 gave a sequence corresponding to the $\alpha$-subclass of Proteobacteria and the nearest neighbor was a Roseobacter sp. (bacterial symbiont of Prionitis filiformis; $97.1 \%$ similarity). DILb-11 corresponded to a sequence related to the gene clone agg58 (98.1\% similarity) found in marine aggregates belonging to the Cytophaga-Flavobacterium group (DeLong et al. 1993).

\section{DISCUSSION}

The physiological state of bacterial cells can be analyzed by a wide variety of methods (Joux \& Lebaron 2000). However, only a few are considered to be uni- versal enough to be applied to natural communities. The CTC method is commonly used to measure the single-cell activity of natural bacteria (Gasol et al. 1995, del Giorgio et al. 1997, Choi et al. 1999, Lebaron et al. 1999). It was recently suggested that CTC+ cells as determined by FCM correspond to cells with a high level of metabolic activity (Sherr et al. 1999). Nevertheless this method remains controversial (Thom et al. 1993, Ullrich et al. 1999), due to the lack of information concerning what its results actually indicate (Sieracki et al. 1999). In this study, the fraction of respiring cells represented less than $3 \%$ of the total number of bacteria, yet the presence of 13 bands, in the corresponding DGGE profile, revealed a large diversity of species. The recovery of 9 of these bands in the community profile indicates that some populations are characterized by a heterogeneity of physiological states including active and inactive cells. Del Giorgio \& Scarborough (1995) mentioned that active cells might be rapidly regulated by unknown mechanisms. Heterogeneity of physiological state could be the consequence of the microscaled aggregative repartition of nutrients in the natural environment. Inversely, if we assume that the detection limit of the DGGE is approximately $1 \%$ of total DNA (Muyzer \& Smalla 1998), populations that were present in the fraction of CTC+ cells and not in the community 
profile (i.e. DILb-6 and -7) may represent active cells of populations that are not numerically dominant and therefore not detectable in the community DNA.

The diversity of species found in the different fractions of culturable cells was significant since a total of 16 different bands were found in these fractions. The diversity of culturable cells varied greatly, depending on the culture media used for their detection. Similar trends were found by Schut et al. (1997). The combination of both R2Am and MA media appeared to allow the isolation of the highest number of strains. Only 1 band present in the culturable cell profiles, and 1 dilution culture strain were detected in the community profile. These preliminary results obtained from both active and culturable profiles suggest that fractionating the community on the basis of various criteria like activity or culturability can improve the number of species detected. Furthermore, it gives the opportunity to clarify their role within the community as (1) active cells at the time of sampling (CTC+ cells), or (2) viable and inactive but potentially activated when environmental conditions become favorable. Nevertheless, culture methods remain essential to isolate, identify and then characterize the physiology of strains that can be related to those detected and identified by cultureindependent methods.

The low occurrence of culturable species in the community DNA profile found in this study is congruent with other results (Ward et al. 1990, Bidle \& Fletcher 1995, Suzuki et al. 1997). Inversely, it does not sustain the results of Rehnstam et al. (1993). These authors compared the abundance of specific culturable bacteria by $16 \mathrm{~S}$ rRNA probing of the bacterial community DNA and by colony hybridization with the same probes. Their results showed no relationship between strength of the hybridization signal towards community DNA and the CFU. Thus, although present in low numbers on the agar plates, the same species may still occupy a significant fraction of the bacterial community. One possible explanation of this discrepancy was thought to be low plating efficiency due to viral infection (Rehnstam et al. 1993). In the present study, the DILb-1 phylotype was affiliated to the Roseobacter genus. In a recent study conducted in the North Sea, Eilers et al. (2000) isolated Roseobacter spp. strains, using an oligotrophic medium, and found clones related to this genus in total DNA. The fact that we did not recover this phylotype among the culturable fraction is not due to the physiological state of its representatives since some of them belonged to the active fraction of the community. In this respect, a viral infection could explain why this species was not detectable by culture.

The occurrence of bacterial growth in unamended filtrates of seawater has been documented extensively (Carlucci et al. 1986, Button et al. 1993, Schut et al.
1993). Since the dilution to extinction method favors the growth of predominant species, the cultures generated from small inocula ( $\leq 50$ total cells) can be addressed as cultures of typical marine bacteria. However, only 1 of the 6 strains isolated from dilution cultures was detected in both whole community and CTC+ profiles. This observation should be related to the low percentage of growth-positive cultures that we obtained at high dilution levels. Button et al. (1993) reported similar results in some cases for which they found a percentage of culturability of about $2 \%$. These authors attributed the low values to the difficulty in detecting small populations or to the fact that inoculated cultures sometimes failed to grow in microbiological experiments for unknown reasons. As suggested by Rehnstam et al. (1993), it is possible that some environmental situations are characterized by the presence of an important viral community or an important proportion of infected bacteria. In such situations, the long incubation period required for dilution cultures could favor bacterial infection or the induction of a lytic cycle for bacteria already infected. However, it was recently reported that viral infection could be very low in the case of Mediterranean bacterioplankton (Guixa-Boixereu et al. 1999). An other explanation is given by the interspecies metabolic relationships which generally occur in ecosystems characterized by a large diversity. Commensalism has been extensively described in soil environments (Waid 1999), but little is known about those interactions in aquatic communities. Genetic diversity analyses of aggregate-attached versus freeliving community have revealed the existence of 2 distinct species assemblages characterized by different and complementary metabolic capacities (DeLong et al. 1993). In this respect, some bacterial cells isolated in dilution flasks may have required the metabolic products of other species to be able to grow. The existence of inter- and intra-species cell-to-cell communication, via chemical signals, has been demonstrated for numerous bacterial species, especially when related to quorum sensing (Bassler 1999). Many studies have suggested the involvement of pheromones in prokaryotic growth and division (Kaprelyants \& Kell 1996). Therefore, the absence of growth in the most diluted flasks may also be explained by the lack of growthinducing compounds secreted by other cells.

Strains other than DILs-1 and DILs-4, which were isolated from dilution cultures, were not detected on culture media. If we assume that the number of culturable cells estimated by both methods was similar, then these differences may be explained in several ways. Strains found in dilution cultures may be sensitive to high nutrient concentrations upon the first isolation and are more responsive to unamended seawater. These species may also be able to grow in the absence 
of competitive species. Surprisingly, all strains isolated from dilution cultures were able to grow at least on 2 of the agar media tested after growth in unamended seawater. These results are not congruent with those of Button et al. (1993) and Schut et al. (1993), who isolated some strains growing in dilution culture but which were not able to post-grow on culture media. However, Schut et al. (1993) reported some reversibility after 1 yr at $5^{\circ} \mathrm{C}$. Strain DILs- 2 was closely related (98\% sequence similarity) to an obligate oligotrophic strain previously isolated in the Pacific Ocean (Katanozoka pers. comm.) that was only able to grow in a diluted Zobell 2216 medium. The strain isolated in this study was able to grow on a nutrient-rich medium (MA). These results further strengthen the argument that oligotrophy may be a reversible property of some strains depending on its environmental context at a given time and physiological history as previously suggested (Martin \& MacLeod 1984, Schut et al. 1993).

\section{CONCLUSIONS}

We are not aware of any other studies that provide genetic information on the diversity of active cells detected by the CTC method. Our results suggest that at a given time, the diversity of active bacteria may be high, and that some active populations may not be detectable at the community level. Furthermore, heterogeneity of physiological states within natural populations was suggested, which sustains the hypothesis that unknown mechanisms regulate the activity of cells in natural communities. The genetic diversity found at the community level does not include all populations playing a potential role in the dynamics of the system at the time of sampling. Some of these populations were isolated in dilution cultures and identified as marine species including obligate oligotrophic species. Most of these, however, were not detected in the fraction of active CTC-reducing cells. Therefore, the community structure, as determined from total cells, did not reflect the diversity of viable species that are also of great ecological interest.

The results of this study support the recent development of new approaches in microbial ecology which were developed to answer the question: What are the fractions of active, inactive, viable and dead cells in natural bacterioplankton assemblages and which species participate in bacterial production? The use of multiple detection methods such as those used in this study will help to isolate and identify a larger number of marine species. These approaches remain essential to promote the development of population ecology and to further understand the ecological role of unknown species.
Acknowledgements. We are grateful to Steve Trosok for language improvements, and to anonymous reviewers for their contribution to the improvement of this manuscript.

\section{LITERATURE CITED}

Altschul SF, Gish W, Miller W, Myers EW, Lipman DJ (1990) Basic local alignment search tool. J Mol Biol 215:403-410

Amann R, Ludwig W, Schleifer KH (1995) Phylogenetic identification and in situ detection of individual microbial cells without cultivation. Microbiol Rev 59:143-169

Bassler BL (1999) How bacteria talk to each other: regulation of gene expression by quorum sensing. Curr Opin Microbiol 2:582-587

Bidle KD, Fletcher M (1995) Comparison of free-living and particule-associated bacterial communities in the Chesapeake Bay by stable low-molecular-weight RNA analysis. Appl Environ Microbiol 61:944-952

Button DK, Schut F, Quang P, Martin R, Robertson BR (1993) Viability and isolation of marine bacteria by dilution culture: theory, procedures, and initial results. Appl Environ Microbiol 59:881-891

Carlucci AF, Shimp SL, Craven DB (1986) Growth characteristics of low nutrient bacteria from the north-east and central Pacific Ocean. FEMS Microbiol Ecol 38:1-10

Choi JW, Sherr EB, Sherr BF (1999) Dead or alive? A large fraction of ETS-inactive marine bacterioplankton cells, as assessed by reduction of CTC, can become ETS-active cells with incubation and substrate addition. Aquat Microb Ecol 18:105-115

Dahllof I, Baillie H, Kjelleberg S (2000) rpoB-based microbial community analysis avoids limitations inherent in $16 \mathrm{~S}$ rRNA gene intraspecies heterogeneity. Appl Environ Microbiol 66:3376-3380

del Giorgio P, Scarborough G (1995) Increase in the proportion of metabolically active bacteria along gradients of enrichment in freshwater and marine plankton: implications for estimates of bacterial growth and production. J Plankton Res 17:1905-1924

del Giorgio P, Prairie YT, Bird DF (1997) Coupling between rates of bacterial production and the abundance of metabolically active bacteria in lakes, enumerated using CTC reduction and flow cytometry. Microb Ecol 34:144-154

DeLong EF, Franks DG, Alldredge AL (1993) Phylogenetic diversity of aggregate-attached vs. free-living marine bacterial assemblages. Limnol Oceanogr 38:924-934

Eguchi M, Nishikawa T, MacDonald K, Cavicchioli R, Gottschal JC, Kjelleberg S (1996) Responses to stress and nutrient availability by the marine ultramicrobacterium Sphingomonas sp. strain RB2256. Appl Environ Microbiol 62:1287-1294

Eilers H, Pernthaler J, Glöckner FO, Amann R (2000) Culturability and in situ abundance of pelagic bacteria from the North Sea. Appl Environ Microbiol 66:3044-3051

Garcia-Pichel F, Prufert-Debout L, Muyzer G (1996) Phenotypic and phylogenetic analyses show Microcoleus chtonoplastes to be a cosmopolitan cyanobacterium. Appl Environ Microbiol 62:3284-3291

Gasol JM, del Giorgio PA, Massana R, Duarte CM (1995) Active versus inactive bacteria: size-dependence in a coastal marine plankton community. Mar Ecol Prog Ser 128:91-97

Gasol JM, Zweifel UL, Peters F, Fuhrman JA, Hagström ^̊ (1999) Significance of size and nucleic acid content heterogeneity as measured by flow cytometry in natural planktonic bacteria. Appl Environ Microbiol 65:4475-4483 
Gonzalez JM, Moran MA (1997) Numerical dominance of a group of marine bacteria in the $\alpha$-subclass of the class Proteobacteria in coastal seawater. Appl Environ Microbiol 63:4237-4242

Guixa-Boixereu N, Vaqué D, Gasol JM, Pedrós-Alió C (1999) Distribution of viruses and their potential effect on bacterioplankton in an oligotrophic marine system. Aquat Microb Ecol 19:205-213

Head IM, Saunders JR, Pickup RW (1998) Microbial evolution, diversity, and ecology: a decade of ribosomal RNA analysis of uncultivated microorganisms. Microb Ecol 35: $1-21$

Joux F, Lebaron P (1997) Ecological implications of an improved direct viable count method for aquatic bacteria. Appl Environ Microbiol 63:3643-3647

Joux F, Lebaron P (2000) Use of fluorescent probes to assess physiological functions of bacteria at single-cell level. Microbes Infect 2:(in press)

Kaprelyants AS, Kell DB (1996) Do bacteria need to communicate with each other for growth? Trends Microbiol 4: 237-242

Karner M, Fuhrman JA (1997) Determination of active marine bacterioplankton: a comparison of universal 16S rRNA probes, autoradiography, and nucleoid staining. Appl Environ Microbiol 63:1208-1213

Lebaron P, Ghiglione JF, Fajon C, Batailler N, Normand P (1998a) Phenotypic and genetic diversity within a colony morphotype. FEMS Microbiol Lett 160:137-143

Lebaron P, Parthuisot N, Catala P (1998b) Comparison of blue nucleic acid dyes for flow cytometric enumeration of bacteria in aquatic systems. Appl Environ Microbiol 64: $1725-1730$

Lebaron P, Servais P, Troussellier M, Courties C, Vives-Rego J, Muyzer G, Bernard L, Guindulain T, Schäfer H, Stackebrandt E (1999) Changes in bacterial community structure in seawater mesocosms differing in their nutrient status. Aquat Microb Ecol 19:255-267

Lee N, Nielsen PH, Andreasen KH, Juretschko S, Nielsen JL, Schleifer KH, Wagner M (1999) Combination of fluorescent in situ hybridization and microautoradiography - a new tool for structure-function analyses in microbial ecology. Appl Environ Microbiol 65:1289-1297

Lovejoy C, Legendre L, Klein B, Tremblay JE, Ingram RG, Therriault JC (1996) Bacterial activity during early winter mixing (Gulf of St. Lawrence, Canada). Aquat Microb Ecol 10:1-13

Ludwig W, Strunk O, Klugbauer S, Klugbauer N, Weizenegger M, Neumaier J, Bachleitner M, Schleifer KH (1998) Bacterial phylogeny based on comparative sequence analysis. Electrophoresis 19:554-568

Maidak BL, Olsen GJ, Larsen N, Overbeek R, McCaughey MJ, Woese CR (1997) The RDP (Ribosomal Database Project). Nucleic Acids Res 25:109-110

Martin P, MacLeod R (1984) Observations on the distinction between oligotrophic and eutrophic marine bacteria. Appl Environ Microbiol 47:1017-1022

Muyzer G (1998) Structure, function and dynamics of microbial communities: the molecular biological approach. In: Carvalho GR (ed) Advances in molecular ecology. NATO Science Series: Series A: Life Sciences. IOS Press, Amsterdam, p 87-117

Muyzer G, Smalla K (1998) Application of denaturing gradient gel electrophoresis (DGGE) and temperature gradient gel electrophoresis (TGGE) in microbial ecology. Antonie Van Leeuwenhoek 73:127-141

Muyzer G, Teske A, Wirsen CO, Jannash HW (1995) Phylogenetic relationships of Thiomicrospira species and their identification in deep-sea hydrothermal vent samples by denaturing gradient gel electrophoresis of $16 \mathrm{~S}$ rDNA fragments. Arch Microbiol 164:165-172

Muyzer G, Brinkhoff T, Nübel U, Santegoeds C, Schäfer H, Wawer C (1998) Denaturing gradient gel electrophoresis (DGGE) in microbial ecology. In: Akkermans ADL, van Elsas JD, de Bruijn FJ (eds) Molecular microbial ecology manual, Suppl 3, 3.3.4. Kluwer, Dordrecht, p 1-27

Pinhassi J, Zweifel UL, Hagström Å (1997) Dominant marine bacterioplankton species found among colony-forming bacteria. Appl Environ Microbiol 63:3359-3366

Rehnstam AS, Bäckman S, Smith DC, Azam F, Hagström Å (1993) Blooms of sequence-specific culturable bacteria in the sea. FEMS Microbiol Ecol 102:161-166

Rodriguez GG, Philipps D, Ishiguro K, Ridgway HF (1992) Use of a fluorescent redox probe for direct visualization of actively respiring bacteria. Appl Environ Microbiol 58: 1801-1808

Schut F, de Vries EJ, Gottschal JC, Robertson BR, Harder W, Prins RA, Button DK (1993) Isolation of typical marine bacteria by dilution culture: growth, maintenance and characteristics of isolates under laboratory conditions. Appl Environ Microbiol 59:2150-2160

Schut F, Prins RA, Gottschal JC (1997) Oligotrophy and pelagic marine bacteria: facts and fiction. Aquat Microb Ecol 12:177-202

Sherr BF, del Giorgio P, Sherr EB (1999) Estimating abundance and single-cell characteristics of respiring bacteria via the redox dye CTC. Aquat Microb Ecol 18:117-131

Sieracki ME, Cucci TL, Nicinski J (1999) Flow cytometric analysis of 5-cyano-2,3-ditolyl tetrazolium chloride activity of marine bacterioplankton in dilution cultures. Appl Environ Microbiol 65:2409-2417

Smith E (1998) Coherence of microbial respiration rate and cell-specific bacterial activity in a coastal planktonic community. Aquat Microb Ecol 16:27-35

Strunk O, Ludwig W (1998) ARB: a software environment for sequence data. Department of Microbiology, Technical University Munich

Suzuki MT, Rappé MS, Haiberger ZW, Winfield H, Adair N, Ströbel J, Giovannoni SJ (1997) Bacterial diversity among small-subunit rRNA gene clones and cellular isolates from the same seawater sample. Appl Environ Microbiol 63: 983-989

Thom SM, Horobin RW, Seidler E, Barer MR (1993) Factors affecting the selection and use of tetrazolium salts as cytochemical indicators of microbial viability and activity. J Appl Bacteriol 74:433-443

Ullrich S, Karrasch B, Hoppe HG, Jeskulke K, Mehrens M (1996) Toxic effects on bacterial metabolism of the redox dye 5-cyano-2,3-ditolyl tetrazolium chloride. Appl Environ Microbiol 62:4587-4593

Ullrich S, Karrash B, Hoppe HG (1999) Is the CTC dye technique an adequate approach for estimating active bacterial cells? Aquat Microb Ecol 17:207-209

Urbach E, Vergin KL, Giovannoni SJ (1999) Immunochemical detection and isolation of DNA from metabolically active bacteria. Appl Environ Microbiol 65:1207-1213

Waid JS (1999) Does soil biodiversity depend upon metabiotic activity and influences? Appl Soil Ecol 13:151-158

Ward D, Weller R, Bateson MM (1990) 16S rRNA sequences reveal numerous uncultured microorganisms in a natural community. Nature 345:63-65

Wintzingerode F, Göbel UB, Stackebrandt E (1997) Determination of diversity in environmental samples: pitfalls of PCR-based rRNA analysis. FEMS Microbiol Rev 21: 213-229

Submitted: April 5, 2000; Accepted: September 12, 2000

Proofs received from author(s): October 27, 2000 